\title{
Elections, Institutions, and the Regulatory Politics of Platform Governance: The Case of the German NetzDG
}

\author{
Robert Gorwa*
}

\begin{abstract}
Policy proposals for higher rules and standards governing how major usergenerated content platforms like Facebook, Twitter, and YouTube moderate socially problematic content have become increasingly prevalent since the negotiation of the German Network Enforcement Act (NetzDG) in 2017. Although a growing body of scholarship has emerged to assess the normative and legal dimensions of these regulatory developments in Germany and beyond, the legal scholarship on intermediary liability leaves key questions about why and how these policies are developed, shaped, and adopted unanswered. The goal of this article is thus to provide a deep case study into the NetzDG from a regulatory politics perspective, highlighting the importance of political and regulatory factors currently under-explored in the burgeoning interdisciplinary literatures on platform governance and platform regulation. The empirical account presented here, which draws on 30 interviews with stakeholders involved in the debate around the NetzDG's adoption, as well as hundreds of pages of deliberative documents obtained via freedom of information access requests, outlines how the NetzDG took shape, and how it overcame various significant obstacles (ranging from resistance from other stakeholders and the European Union's frameworks against regulatory fragmentation) to eventually become law. The article argues, throughout this case study, that both domestic politics and transnational institutional constraints are crucial policy factors that should receive more attention as an important part of platform regulation debates.
\end{abstract}

\section{Introduction}

On the 1st of January 2018, the Gesetz zur Verbesserung der Rechtsdurchsetzung in sozialen Netzwerken went into effect in Germany (literally, the legislation

* Department of Politics and International Relations, University of Oxford. Orgorwa. This is the pre-publication accepted manuscript $(C C-B Y-N C-N D$ 4.0), please refer to the final copy for page numbers: Gorwa, R. 2021. Elections, Institutions, and the Regulatory Politics of Platform Governance: The Case of the German NetzDG. Telecommunications Policy 45 (6), 102145. doi:10.1016/j.telpol.2021.102145 
to improve law enforcement in social networks, commonly shortened to Netzwerkdurchsetzungsgesetz, or 'Network Enforcement Act' in English, with the abbreviation NetzDG commonly used in both German and English-language writing about the regulation). The law became probably the first regulation in the world to directly proscribe how large user-generated content platforms moderated harmful content, establishing background standards for how firms set up their complaints handling procedures, mandating a designated contact point through which the authorities could channel specific inquiries and complaints, and setting up a level of mandatory transparency reporting for platform content moderation. At the core of the NetzDG was an obligation that companies remove content that was 'manifestly illegal' under a set of provisions in the German Criminal Code within 24 hours of it being notified. These new rules were underpinned by an enforcement mechanism that threatened fines of up to 50 million Euros in the case of multiple, systemic violations 11

The NetzDG has always been a controversial and politicized piece of legislation. In Germany, industry and civil society joined together to advocate against the law, its adverse potential impacts for freedom of expression, and the possibility that the financial sanctions would incentivize companies to over-remove reported content (He, 2020; Schulz, 2018; Tworek \& Leerssen, 2019). A growing body of legal literature has assessed the implications of the NetzDG for platform regulation, focusing on three issues: the legislation's normative conflict with international human rights standards (Schulz, 2019), its tension with preexisting European legal frameworks (Spindler, 2017; Claussen, 2018), or how it may not in practice even deliver upon the policy outcomes it was supposed to deliver (Heldt, 2019a) ${ }^{2}$ While these existing academic accounts have done invaluable work towards understanding the legal and normative implications and shortcomings of the NetzDG, and have grounded it within a broader global context, current debates around the law - as well as content-related platform regulation mode broadly - are missing a key dimension: regulatory politics. Considering the NetzDG through the lens of what Farrell and Newman (2010, p. 611) call "international market regulation," or "the processes through which the domestic regulatory activities of states and other actors set the effective rules of internationally-exposed markets," highlights several hereto underexplored political and institutional factors that were at play during the NetzDG's negotiation, implementation, and enforcement, including the role of parliamentary time constraints, regulatory harmonization frameworks, and negotiations between the European Commission and German lawmakers.

The goal of this article is to thus provide a more complete consideration of the regulatory politics of the NetzDG, taking it as a critical episode within the recent regulatory conversation on 'platform governance' (Flew and Wilding, 2020; Gorwa, 2019). Drawing on thirty interviews conducted with German and European policymakers and other stakeholders active in the regulatory debates

\footnotetext{
${ }^{1}$ An English version of the final version passed in 2017 is available at: https://perma.cc/E3WA-B2SR

${ }^{2}$ For more supportive accounts from a German perspective published in English, see Wischmeyer (2018), Theil (2019).
} 
during the lead up to the NetzDG, as well as primary source documents obtained via freedom of information requests made to various German and European institutions, I seek to map out the origins of the law, and how its features evolved from a voluntary, collaborative 'Task Force' on hate speech set up by the German Ministry for Justice and Consumer Protection into a statutory piece of legislation. This more political, rather than legal account highlights the various points at which the development of the law was influenced by domestic politics and overarching institutional constraints. In particular, I discuss the initial regulatory framework set out in the Task Force, which appeared to create some important path dependencies once demand for binding rules to govern online content emerged in the German governing CDU/SPD coalition in the lead up to the 2017 elections. Additionally, I discuss the hereto unexplored role played by the regulatory harmonization frameworks of the European Union, especially the TRIS framework for notifying new technical regulations to the European Commission. I demonstrate that this framework, when coupled with very strong domestic demand for new rules, helped entrench what even the law's supporters saw as a less than optimal eventual outcome.

The goal of this account overall is to not only add to the growing debate and literature on the NetzDG and other similar regulatory initiatives, but also to broaden the current conversation on platform content regulation to engage more deeply with complex political and regulatory factors. The article begins with a brief overview of the article's conceptual framework of platform governance and regulatory politics, and outlines the empirical methods deployed. The central case study follows.

\subsection{A Regulatory Politics Approach to Platform Gover- nance}

Platform governance - how platform companies set and enforce standards around their platform's use, and how others seek to influence or control that process - has in the past five years become a highly contentious global regulatory issue (Kaye, 2019; Arun 2018). Since 2015, there have been multiple overlapping efforts by various states to try and govern the content moderation practices of companies, taking on a wide variety of institutional forms that range from domestic statutory legislation to more flexible 'co-regulatory' initiatives and private industry-led organizations (Gorwa, 2019a, 2019b). The most important work on this development has largely been conducted by legal scholars, especially experts in intermediary liability and international human rights law, who have scrutinized both the emerging systems of private platform rulemaking (Klonick, 2017; Kettemann \& Schulz, 2020) and assessed the major developments in government regulation (Keller, 2018; Frosio, 2018; Kuczerawy, 2018; Suzor, 2019).

This legal scholarship has proven extremely valuable, not only for increasing our general understanding of online content regulation, but also for increasing its global salience as an important issue. Nevertheless, from a policy studies perspective, it might be said to have a few limitations. First, while legal scholars 
tend to become interested in analyzing legal frameworks and their implications once they are enacted and codified, and their work usually does not explicitly engage with the process of rulemaking itself, or directly scrutinize the various interests, choices, and tradeoffs that affected the specific character of the (public or private) rules that were adopted. Secondly, it frequently has a normative dimension, assessing rules based upon assumptions about the impact that those rules may have on the customers using platform services. While this is in many ways admirable and important, the focus of this scholarship is not usually to scrutinize the specific facets of how certain political negotiations, factors, or interest configurations lead to certain sets of potentially rights-infringing rules (and thus how alternative outcomes may have been achieved), but rather, to critique and to propose policy alternatives.

A regulatory politics approach to the governance of, and by platforms would highlight slightly different issues and analytical considerations. Drawing upon conceptual tools from various subsets of international relations and political science, especially literatures on international political economy, transnational regulation, and global governance, a regulatory politics lens conceptualizes platform governance as primarily a process of regulatory contestation, where the process of rule creation is an an inherently political process, subject to negotiation between varying actors. Rules, meaning both private platform politics and practices as well as the regulatory frameworks created by states seeking to govern those policies and practices, might be influenced by a wide range of factors including domestic and transnational power relationships, electoral considerations, regulatory capacity, pre-existing institutional bargains, and normative characteristics, such as reputation, legitimacy, conceptions of the appropriate scope of policy intervention.

If, in the absence of major international fora for digital policy decisionmaking at the content or application layer of the internet, platform rules are shaped by domestic regulations in various jurisdictions, as well as a smaller number of informal and voluntary transnational governance initiatives, this means that platform governance is likely to be significantly shaped by domestic and transnational institutional structures (Bannerman \& Haggart, 2015). It is a complex undertaking, but there have been a few recent efforts to assess selfregulatory and informal regulatory initiatives for platform content through this lens (e.g Medzini, 2021; Gorwa, 2019a). Notably, the foundational work of Haggart (2014) has engaged with broader online content issues via study of the politics of global copyright, and has more broadly sought to insert more concepts and frameworks from global governance and international politics into the platform governance discussion (Haggart and Keller, this issue).

While a fuller exposition of this research agenda could serve as the basis of a standalone article (see Gillespie et al. 2020 for another brief analysis), the summary is that the process of setting standards around content moderation for major user-generated content platforms should be seen an inherently political practice, and a site of political contestation where multiple actors compete to shift the regulatory status quo towards outcomes that bring them economic or political benefit. This requires slightly different analytical tools, and different 
methods than common in extant legal approaches.

\subsection{Methods}

A regulatory politics framework for platform governance issues offers many potential methodological tools common in the regulatory politics literature, where everything from case studies and process tracing to sizable regulatory datasets have been deployed to assess regulatory developments in various global industries (Mattli \& Woods, 2009; Westerwinter 2021). For research that is seeking to understand the processes of institutional and regulatory change, qualitative methods are generally deployed: in particular, case studies using process tracing, interviews, and primary archival material (Farrell \& Newman, 2010, p. 627). These techniques lend themselves well to the multidimensional and complex political relations that drive regulation, and that cannot be easily abstracted away via large-scale models or quantitative analysis. Rather than taking a causal approach, this article takes an inductive and exploratory analysis into the political factors underpinning the NetzDG regulatory process in order to provide a probability probe for the applicability of the broader regulatory politics agenda discussed above to key episodes of platform regulation. Two main methods commonly used in regulatory politics scholarship were deployed: qualitative interviews with elites and stakeholders involved in the debates (Leech, 2002); and close analysis and thematic coding of primary source documents, including new documents obtained via freedom of information access requests.

More than thirty interviews conducted with German and European policymakers that participated in the policy debate around the NetzDG from 20152017. These interviews were conducted with members of all three broad stakeholder groups involved in the policy process (government, firm, and civil society), and included members of the Bundestag and their staff, civil servants in the European Commission up to the Commissioner level, as well as the policy employees of the major platform companies and civil society groups involved both in Germany and the EU. These interviews were largely sourced via a snowball sampling process, following an initial purposive sample of key individuals involved 3

Alongside these interviews, primary policy documents were obtained from the usual official sources, as well as from publicly available documents that individuals had previously requested via the transparency platforms AsktheEu and FragDenStaat (see Table 1 and 2 in the appendix). Alongside this collection, new documents were obtained via freedom of information access (FOIA) requests made to the German Ministry of Justice and to various European Commission Directorate Generals via these two platforms. Through these requests, I received internal correspondence (emails and letters), draft policy briefs, and other internal decision-making documents that were deemed appropriate for

\footnotetext{
${ }^{3}$ The project received approval from the University of Oxford's research ethics committee (CUREC \# SSH_DPIR_C1A_18_018), and followed the best practices for human-subjects research outlined by the Association of Internet Researchers and the American Political Science Association. A list of interviewees that agreed to be listed is available in the appendix.
} 
public release by the relevant ministry. While some of these documents were quite heavily redacted, I obtained more than five hundred pages of documents that help provide new insight into some of the key decision points being taken during the NetzDG negotiations, especially from the perspective of the European Commission.

\section{Case Study Part One: The 'Task Force'}

\subsection{Regulatory and Political Context}

In 1997, the European Commission published a communication on European commerce, which kicked off a regulatory process that eventually resulted in the E-Commerce Directive (2000/31; the ECD). The ECD sought to harmonize European rules for 'information society services' provided by a wide range of different online intermediaries, from network operators (e.g telecommunications companies), search engines, web hosting providers, and social networks (Baistrocchi, 2002), with the goal to reduce diverging national standards for marketing and contracts, liability of intermediaries, and help remedy the question of jurisdictional conflict within the EU, where businesses may have faced legal uncertainty about which national rules should apply for cross-border services (Hellner, 2004). While the specifics of this system have become more complicated in the past two decades, with a growing turn towards co-regulatory and collaborative regulatory arrangements for various digital policy domains built upon this status quo (Frosio, 2018; Marsden, 2011), the regulatory status quo governing content in the mid-2015 for major platform companies operating in Germany was effectively the laissez-faire system of notice and takedown that had been established under the E-Commerce Directive, and nationally enshrined in the German Telemedia law. Major platforms operating in Germany followed a transnational set of varying voluntary and binding commitments with overlapping jurisdictional scope, through organizations like the Global Network Initiative, the Freedom Online Coalition, and commitments made under voluntary and co-regulatory initiatives coordinated through the European Commission, such as the CleanIT project and other efforts to combat harmful content that could endanger child safety (Livingstone, Ólafsson, O'Neill, \& Donoso, 2012).

In the German context, the frequently identified turning point for the platform governance status quo followed the Syrian conflict, and the displacement of millions of asylum seekers into Europe. In the summer of 2015, Germany, economically and politically the most powerful state in the European Union, decided to break with the established EU resettlement approach under the Dublin Regulation, stating that they would accept asylum claims from Syrians even if their port of entry into Europe was another country (Dernbach, 2015; Hinger, 2016). This policy move was morally laudable but politically controversial, catalyzing far-right extremist groups opposing the re-settlement of refugees in Germany (Dostal, 2015), eventually manifesting in anti-refugee rallies and physical assaults upon immigrants. The number of reported criminal offenses targeting 
refugee re-settlement facilities would skyrocket from only 24 in 2012 to several hundred in 2015 (Gathmann, 2015), prompting a heated national conversation on immigration, racism, and multiculturalism.

As the humanitarian crisis unfolded, so did the apparent visibility of farright extremism and islamophobia on major social networks. Major figures in German politics, including Merkel herself, were being targeted by online harassment and threats, and commentaries in the country's largest newspapers had begun to point the finger at the content standards on Facebook and Twitter. For example, an emblematic article published in Der Spiegel, the weekly news magazine with the largest such circulation in Germany, posed the question of "Why Facebook doesn't delete Hate," bringing up multiple anecdotal instances of public comments left on the Facebook pages of German news outlets not being removed despite being user reports (Reinbold, 2015). The article noted that Facebook was extremely opaque about its content moderation processes - what the exact rules against racist content were, and how those rules were enforced, and by whom - arguing that the company appeared to conduct moderation via a network of contractors in Dublin, India, and the US, but apparently had no actual content moderators in Germany itself.

Amidst these external political shocks, dissatisfaction with the regulatory status quo began to build amongst key German decision-makers. The most important of these was Heiko Maas, who became the SPD Minister of Justice and Consumer Protection in a CDU-led grand coalition government formed following the 2013 election. Maas was a vocal critic of right-wing extremism and anti-refugee sentiment, speaking out on numerous occasions against far-right and anti-immigration political movements in 2014 and 2015, and was an active social media user (Vasagar, 2014). In the summer of 2015, he wrote a letter to Richard Allan, Facebook's head of public policy for Europe, in which he voiced his displeasure with how the company had been handling complaints around illegal or harmful speech, including slurs directed towards refugees and immigrants. Maas noted that "Facebook users are, in particular, complaining increasingly that your company is not effectively stopping racist 'posts' and comments despite their pointing out concrete examples" (Kirschbaum, 2015), in an early indication that there was significant dissatisfaction with the regulatory status quo at the executive level in the German government. The language of Maas' letter was the public articulation of what some digitally oriented policymakers had been arguing for several years: that the status quo for how major platforms conducted content moderation was shifting from 'an imperfect but good enough' situation towards one where the rules were wholly unacceptable ${ }^{4}$

On the 14th of September 2015, Maas met with Facebook's Richard Allan, and at a short press conference that followed, announced that the two had agreed to create a collaborative and voluntary regulatory initiative which would address standards around illegal online hate speech. Through this new 'Task Force Against Illegal Online Hate Speech', the Minister promised to engage both

${ }^{4}$ See for example the writing of Konstantin von Notz and others in the Green Party: https://perma.cc/R377-PGLR 
Facebook and civil society stakeholders in order to produce "concrete measures" for the companies to implement by the end of the year 5 In an interview that was published a few days later by the Jüdische Allgemeine, a newspaper serving the German-Jewish community, Maas delivered a simple message that would become the catch-phrase of the Ministry's effort to regulate social networks. As he vowed to fight against online anti-semitism and other forms of platformmediated hate, he stated simply the Task Force's aim to bring the rule of law to the online sphere: 'was offline verboten ist, ist auch online nicht erlaubt' (what is forbidden offline is also not allowed online) (Krauss, 2015).

The Task Force had its first meeting ten days later in Berlin. Following an opening by Gerd Billen, the most senior civil servant in the Ministry of Justice, who had been tapped by Maas to lead the Task Force, the meeting featured presentations from Facebook and Google and concluded with inputs from the handful of civil society and hybrid civil society/governmental organizations that attended ${ }^{6}$ At the onset, very little public information was released about the project, and detailed meeting minutes were not kept.7 The task force had 4 meetings in 2015: September 25, October 10, December 7, and December 15, with the participants including representatives from Facebook, YouTube, and Twitter; the industry associations eco and FSM; and four German organizations working on issues relating to child protection, racism and far-right extremism 8 Together, the participants in the working group began negotiating a possible set of commitments to create, with Ministry officials pushing for content reported in Germany to be reviewed in Germany and for broader application of German law rather than company community standards.

On December 15, after a 4th meeting of the group, a 5-page 'results paper' (ergebnispapier) from the Task Force was published. This document sets out the "concrete measures" that Maas had promised by the end of the year when announcing the initiative, and in it, the companies make a number of commitments to improve their standards for complaints processing "by mid-2016." This document does not explicitly refer to itself a code of conduct, but in interviews conducted with individuals who attended the Task Force's meetings, the interviewees referred to a "code of conduct" as the central result of the Task Force ${ }^{9}$ The main take-away of the document is its emphasis the companies will act against "all hate speech prohibited against German law" and "review and remove without delay upon notification." 10 To achieve that goal, the document

\footnotetext{
${ }^{5} \mathrm{~A}$ video of the press conference is available available at: https://perma.cc/7D2M-5B9V

${ }^{6}$ Partial agenda summaries are available on an archived Ministry webpage.

${ }^{7}$ In a freedom of information request to the Ministry, to obtain the meeting minutes for the Task Force, the ministry responded that they did not exist (Frag den Staat, 2017).

${ }^{8}$ These were Jugendschutz.net, klicksafe.de, the Amadeu Antonio-Stiftung, and Gesicht Zeigen. While the Amadeu Antonio foundation and Gesicht Zeigen are independent civil society organizations, Jugendschutz and Klicksafe are probably better understood as governmental actors or quasi-governmental actors with close ties to the German state and federal governments. Klicksafe is a EU funded project of the state media regulators of Rhineland-Palatinate and North Rhine-Westphalia.)

${ }^{9}$ Interviews conducted in 2020 with Simone Rafael, Antonio Amadeu Stiftung; Lutz Mache, Google Germany.

${ }^{10}$ Quotes from p. 1 of Ministry's official English translation, obtained by EDRI The German
} 
outlines a few 'best practices' and other commitments that have varying levels of clarity and ambiguity. The three main parts of these commitments are published in an infographic that Maas then shared on Twitter, which summarizes the code of conduct for the public as follows: companies (a) agree to respect German law (in other words, what is illegal offline should be illegal online), (b) agree to remove reported content in less than 24 hours, and to (c) improve their user-reporting tools 11

The companies agreed to implement the terms of the code of conduct in the next six months, but this was an informal agreement, and the publicly-released results paper was not undersigned by the companies or specific employees. However, the Ministry faced challenges with implementation. How to ensure whether the companies were implementing the (for the most part, flexible and general) commitments, and to measure whether these were actually having an effect?

\subsection{Implementation Difficulties}

On the 11th of April 2016, press releases from the German Ministry for Family Affairs and the Ministry of Justice announced that the two ministries would be working together to commission a monitoring exercise to evaluate the effects of the Task Force's voluntary commitments (BMFSFJ, 2016). This informal evaluation would be performed by Jugendschutz.net, an organization that was established in 1997 with funding from the Ministry of Family Affairs and serves as a 'centre of competence' for the German states on child protection issues. Since 2008, Jugendschutz has been conducting research and advocacy into online child safety, with a legal mandate set out in the Interstate Treaty on the Protection of Minors (Jugendmedienschutz-Staatsvertrag, JMStV). Beyond actively searching out illegal content and reporting it to the platforms (in their 2008 annual report, for instance, they claim that they successfully were able to secure the removal of 1400 illegal videos from YouTube either in Germany or globally), they had from 2008 onwards conducted a number of simple audit studies, in which their employees would proactively attempt to find illegal content on search engines or social networks (Glaser, Günter, Schindler, \& Steinle, 2008). Through a collaboration with the Ministry of Justice, Jugendschutz brought some research capacity and expertise when it came to content moderation standards, even though their thematic focus was on a different issue area (hate speech, and not child protection). As the BMJV's Gerd Billen noted in a statement, the monitoring would be an "important component of the task force" :

The monitoring provides us with important insights into how agreements with companies work in practice, how quickly they react to reports and whether they delete the reported illegal hate content. This will enable us to better assess how the agreed measures are

version is archived at https://perma.cc/J35T-DGC6

${ }^{11}$ Maas' tweet at the Web Archive. 
taking effect and what further steps are necessary (BMFSFJ, 2016, $\mathrm{np}$, author translation).

Jugendschutz employees conducted their first formal evaluation in July 2016 , by which the firms were supposed to have implemented the code's commitments (Jugendschutz, 2016). The results were not in line with the Ministry's expectations. As Maas later summarized at a public event, the figures released by Jugendschutz, based on a small sample of content takedown requests, suggested that "of the illegal content reported by users, Twitter deletes about $1 \%$, YouTube just 10\%, and Facebook about 46\%"(Reuters, 2016). Shortly following the evaluation, Maas wrote again to Richard Allan and to Facebook's head lobbyist in Berlin. In the letter, obtained by a freedom of information request, Maas wrote that "the results of your efforts thus far have fallen short of what we agreed on together in the Task Force" (Beckedahl, 2016, author translation). In full awareness that the Task Force commitments were voluntary, and thus there were no sanctioning mechanisms or enforcement capabilities built in, he threatened action at the European level if Facebook did not step up their game - writing that he had been discussing the issue with other Justice Ministers in the European Council and that they 'shared his concerns', suggesting that he would seek to influence his European counterparts towards pursuing harder and costlier forms of regulation at the European level. (Despite the even poorer performance displayed by Google and Twitter on those same metrics collated by Jugendshutz, it does not appear as if similar letters were sent to Google or Twitter representatives, as they were not also included in FOIA requests that resulted in the publication of the Facebook letter).

\section{Case Study Part Two: The NetzDG}

As Jugendschutz conducted their evaluations of the implementation of the Task Force's code of conduct, the issue of platform rules in Germany just continued to build. First, domestic legal developments were leading lawmakers in the governing coalition to follow in Maas's footsteps and worry that German law was inadequately being enforced in Germany due to jurisdictional issues, including a decision by a regional court in early 2016 to deny a high-profile complaint against Facebook on the grounds that the court could not make binding decisions over content given that Facebook's European headquarters were in Ireland (Tworek, 2021).

In multiple interviews undertaken with lawmakers and their staff involved in the policy debate at the time, deep frustration was expressed about the opacity of the companies (especially Facebook) and their unwillingness and/or inability to speak candidly about how they enforced their global content moderation rules in the German context. When firm representatives offered testimony to parliamentary committees or at public events, they refused to provide what was perceived to be basic detail about the number of German-speaking content moderators that they employed and their specific capacities in Germany. (At the time, the firms were extremely cagey about who and how these processes 
functioned; as Tarleton Gillespie [2018] and others have noted, this served as a strategy to avoid scrutiny and de-emphasize the importance of their moderation practices). But this strategy appeared to backfire in the German context. As one staffer, the digital policy adviser to a Member of the Bundestag on the Digital Agenda committee noted, in effect "Facebook told [German lawmakers] to their faces that 'yes, the issue is complicated, but we're sorry, but we can't accept your national laws."' 12

Through the Task Force, the salience of these issues increased, and helped lawmakers in the governing coalition to specifically articulate what kinds of rules they wanted to improve transparency reporting and content enforcement standards. Despite the collaborative measures instituted voluntarily by the companies through the task force, in the executive, the perception was that the firms were merely doing "whatever they could to avoid regulation totally and limit their costs", as one Member of the Bundestag in the governing coalition put it ${ }^{13}$ The second major development that drove domestic demand for higher standards for platform content moderation practices was the election of Donald Trump to the US Presidency in November 2016, following a scandal-filled and salacious campaign where social media platforms, foreign interference, and the influence of 'fake news' were all said to have played an outsized role (Karpf, 2017). Following a strong performance by the far-right AfD party in a number of 2016 German state elections, where the AfD, in a number of cases, appeared to take votes from both the CDU and the SPD, concern was mounting in the governing coalition that digital trickery could have an adverse effect on their electoral outcome in the German Federal election that would be happening in Fall 2017. As Gollatz \& Jenner (2018) have argued, the US election's 'fake news' discourse rapidly entered the domestic debate on the NetzDG and helped significantly increase its salience as an issue in the German media.

As domestic pressure for changes to the laissez-faire status quo built, multiple options were on the table. The Ministry could have also continued to work with the existing Task Force structure, expanding upon the code of conduct to incorporate more stringent standards or some kind of better industry auditing and monitoring, implementing some kind of data sharing or other monitoring mechanism. This would have been a relatively low cost option, given that the Task Force structure had already been created, and there were obvious ways to improve that mechanism's commitments and capabilities. For instance, the 'monitoring' that ended up being conducted by Jugendschutz was crude and unscientific, constrained by a lack of proper access to platform data and without a proper sampling strategy ${ }^{14}$ Despite the lack of proper experimental design,

\footnotetext{
${ }^{12}$ Interviews conducted in 2019 and 2020 with governing coalition policy staffers that requested anonymity.

${ }^{13}$ Interview conducted in 2020 with Jens Zimmerman, SPD Digital Policy Spokesman and Member of the Bundestag (2013-)

${ }^{14}$ As German law professor Marc Liesching established through correspondence with the Ministry of Justice, the Jugendschutz team that conducted the monitoring was not composed of lawyers, and given the complex nature of some German criminal statutes, it is unclear that "legal laypersons" were actually able to identify precisely what exactly constituted illegal content under the German Criminal Code (Liesching, 2017). Likewise, the content was never
} 
that third-party monitoring was then used as the only data point to show that the Task Force efforts had failed (Liesching, 2017). The Ministry evidently had the option to continue to improve and refine the collaborative approach if it had wished, however, it appears that collaborative and non-binding rules were no longer satisfying the demand which had in the past year outgrown Maas and spread to the rest of the governing coalition. This made working within any voluntary approach no longer likely to sufficiently fulfill that domestic demand.

The executive could have also worked cooperatively at the EU level: since the Task Force had gone into effect in late 2015, a few new collaborative efforts had been instigated at the European level, the most notable of which was the EU Code of Conduct on Illegal Online Hate Speech (Gorwa, 2019a). While the EU Code remained largely insulated from the similar German collaborative efforts that were happening around the same time, and did not feature prominently in the domestic German debate, Maas and the executive could have tried to build upon the Code of Conduct, trying to bring the German efforts to a broader and collaborative pan-European strategy through which to raise content moderation standards for platforms.

The costliest strategy would have been to try and effect changes to the broader, EU level regulation that underpinned how companies conducted their notice and takedown procedures. However, the Juncker commission had already stated that they were unwilling to re-open the E-Commerce directive for debate (Frosio, 2017), making efforts to try and force the matter especially costly. Instead, on March 14th, the same day that the final Jugendschutz monitoring report about the Task Force code was published, Heiko Maas presented a new draft law. In the initial 29 page document that was released, the following obligations were set out for the regulatory targets ${ }^{15}$ firms would have to (a) publish a quarterly report on the handling of complaints about illegal content; (b) delete obviously illegal content within 24 hours, other illegal content within 7 days; (c) appoint a contact person to receive government queries and complaints in Germany; (d) inform users about content moderation procedures; (e) save deleted content for prosecutors to use as evidence, and (f) immediately delete copies of the relevant content on the platform. The ministry further outlined the estimated costs that would be an outcome of the regulation: approximately 28 million Euros in annual compliance costs for all firms, reflecting increased staffing costs and the cost of putting together the transparency reports, and an estimated 3.7 million Euros annually in terms of bureaucratic costs for the government to account for the additional personnel needed to implement and enforce the new law.

archived before flagging by Jugendschutz, so it is unclear whether the flagged content was actually illegal in Germany or just removed or not removed under the platforms broader 'community standards.'

${ }^{15}$ Defined broadly in the first draft as 'service providers who operate platforms on the Internet with the intention of making a profit which enable users to exchange, share or make available to the public any content with other users (social networks)', with the exclusion of journalistically curated services where an editor is responsible for content under existing legal frameworks (e.g. newspapers, broadcasters). The first draft is available at https://perma.cc/9Z98-WZP7 
Most of these measures followed the agenda established in the Task Force, including the notion that there should be a contact person to handle official complaints, that content moderation standards and complaints procedures should be transparent enough to be clear to users, and that they should generally act on content within 24 hours of it being reported. However, there were also several new and quite aggressive provisions proposed in the draft, which reflected the higher levels of demand in the governing coalition for standards higher than when the Task Force had been created. These provisions included an obligation for firms to delate duplicates of the content that was deemed manifestly illegal under the NetzDG across their broader platforms (in effect searching for copies of content found to be illegal that had not yet been reported), and a requirement that this deleted content would be archived for potential access by federal prosecutors seeking to bring charges against individuals.

\subsection{Civil Society Concerns Meet Electoral Considerations}

Upon the NetzDG's announcement, the backlash from digital civil society and human rights organizations was swift. A number of civil society organizations, including the German digital rights organization Digitale Gesellschaft (2021) and the global press freedom organization Reporters Without Borders (2017) likewise predicted that the law would have deleterious effects on freedom of expression. D64, a network of digital policy experts that is closely linked to the $\mathrm{SPD}$, called the law (and specifically, it's provision for the automatic deletion of matched content) "the first step in a creation of a censorship infrastructure" (Reuter, 2017b, author translation). Industry was unsurprisingly also strongly opposed to the proposal: Bitkom, an industry lobby group that counts Facebook, Twitter, and Google amongst its members, immediately issued a statement warning that the law would spur a "deletion orgy" (Löschorgien) as firms would be incentivized to over-remove content rather than face fines for acting too slowly (Reuter, 2017b).

In the days that followed the draft legislation's announcement, a range critiques were published that pertained to the deleterious potential impacts of the NetzDG being passed. Advocates for free expression, including the UN Special Rapporteur for freedom of opinion and expression, who would eventually write a letter to the German executive branch warning against implementing the NetzDG, noted that the law would incentivize the overblocking of legitimate speech by users, as it was formulated around the main metrics of 'takedowns' and 'speed,' with no real mechanism for auditing the rates of false-positives made by the companies (Kaye, 2019). The second commonly made related argument complained that the NetzDG created a system of 'privatised enforcement,' where the firms would be placed in a position where they were making decisions about the scope and implementation of German law, thus in effect taking this function away from the judiciary and its checks and balances (Coche, 2018; Heldt, 2019b). As the advocacy journalism website Netzpolitik put it, under the NetzDG framework, the platforms would "suddenly become the investigator, judge, and executioner" (Reuter, 2017d). A third argument warned 
that the law, as perhaps the first in the world to regulate content moderation as done by platforms, and due to being proposed by such an internationally influential and democratically legitimate state like Germany, would serve as a model for other less-democratic governments seeking to bring social media companies under closer state control (He, 2020; Schulz, 2018). The furor was intense and as the critiques in major media outlets circulated widely, Maas had to answer the critics as he conducted interviews with major newspapers on other policy matters (Gathmann \& Knaup, 2017), and debated members of civil society groups in public events (Strathmann, 2018).

As the bill entered its first reading and was debated on the floor, Maas defended his bill, arguing that it would not lead to privatized enforcement but rather simply to the more thorough existing implementation of German criminal law. Members of the opposition noted that the list of criminal code statutes covered in the NetzDG were extremely broad and went beyond just hate speech (more than 20, including not just incitement to violence and the promotion of unconstitutional organizations, but also defamation and some oddities like the disparagement of the ceremonial President of the Federal Republic), and that the definition of social networks provided in the bill would likely encompass many other online services, like blogs, third-party reviewing sites, and messaging services like WhatsApp or Telegram. Multiple members of the Bundestag in both the governing coalition and the opposition complained about the very short time period in which the law was being debated. As Netzpolitik's Markus Reuter observed, "all of the CDU/CSU speakers complained about little time remaining until summer break" as they proposed their suggestions for changes, including a bigger role for some kind of self-regulatory body used in the media industry to adjudicate on complaints, rather than the platforms themselves (Reuter, 2017a, author translation). Similarly, MdB Petra Sitte of die Linke argued in her remarks that given the "broad alliance of organizations that had already formed against the draft law" the governing coalition should "engage in a broad discussion" and revisit the issue following the election to prepare a better proposal (Deutscher Bundestag, 2017b, author translation).

Nevertheless, lawmakers in the governing coalition, who held a majority sufficient to pass the legislation if they wished, were supportive of the bill, downplaying the risks and emphasizing the importance of taking a strong position in fighting against illegal content online. The bill appeared to have significant support in the governing CDU/CDU coalition; the legal policy spokespersons for the Union parliamentary group went as far as to say that "The bill by Minister of Justice Maas is a first, small step in the right direction. But we must go much further," suggesting that other types of criminal law enforcement could be also included (Reuter, 2017b, author translation). A few voices in the coalition expressed opposition - parliamentarians active on digital issues, who had ties to the digital civil society organizations and had above average knowledge on digital policy issues, tended to share at least some of the publicly articulated reservations ${ }^{16}$ - but these dissidents were not in the most powerful positions

${ }^{16}$ Interview held in 2020 with anonymous Member of the Bundestag. 
within the party or may not have voiced their concerns publicly.

\subsection{The Debate Inside the Commission}

While this debate was going on domestically within Germany, political actors in the European Union's governing institutions were watching closely and deciding exactly what their position should be. On the 27th of March, the Ministry of Justice notified the proposed law to the European Commission, under the auspices of the Technical Regulation Information System. The German notification was cutting it extremely close to the last possible date that they could notify: because of the layout of the parliamentary calendar in the election year, the parliament would adjourn for the summer break (and then the election) in July. Three months after March 27 was the week of June 26, the final session of the Bundestag for $2 0 1 7 \longdiv { 1 7 }$

When the German Ministry of Justice and Consumer Protection notified the first draft of the NetzDG through the Technical Regulations Information System on March 27, that notification was flagged as potentially politically sensitive, according to Commission emails obtained via freedom of information requests. An internal email from a staffer in the DG for the Internal Market (DG GROW) - the entity in-charge of managing the TRIS notification system - to other GROW staffers, including members in the office of Internal Market Commissioner Elżbieta Bieńkowska, summarized the main points of the NetzDG, the timeline for reactions from the Directorate Generals for Justice (JUST) and Communications, Content, and Technology (CNECT), and the legal deadline for the Commission or Member States to react. The summary of the notification discusses the political context, and notes that DG CNECT is keeping the option of vetoing the law on the table, which can be done if the Commission wishes to pursue a different regulatory strategy:

The German intention to regulate the matter has been recently discussed between CNECT's Cabinet and the German authorities. During these discussions, CNECT informed the German authorities of CNECT's intention to regulate the same matter with a different approach than the one presented in the notified draft. It seems that DG CNECT and DG JUST are in contact to discuss the notified draft and have contacts with the German Ministry of Justice (which prepared the notified draft) ${ }^{18}$

Before the NetzDG had come onto the scene, the Commission had taken the position that no legal framework to raise content moderation standards for major social media platforms was necessary. DG JUST had negotiated a Code of Conduct on Hate Speech with the major internet companies in the Spring of 2016, and Vera Jourova, the EU Justice Commissioner, was publicly a major

\footnotetext{
${ }^{17}$ See the Bundestag Sitzungkalender 2017, archived at https://perma.cc/8WKC-5VFT

18 Gorwa FOIA to DG GROW, 2020. Document received June 9, 2020; document dated April 3, 2017,
} 
advocate for voluntary self-regulation and co-regulation in areas that would have a major impact on free expression and other fundamental rights (Stupp, 2018). In the internal assessment prepared by DG CNECT and JUST, contextualizing the NetzDG within previous Commission measures, Commission staff note that the spirit of the proposal was not totally out of line with their efforts to increase transparency for company content moderation systems and move their private law into a space that it more adequately reflected European legal frameworks:

While, unlike the [EU Hate Speech] Code of Conduct, the draft German law is a legal instrument, an analysis of its objectives against the objectives pursued in the Code of Conduct shows that the two are broadly coherent in terms of the overall objective. Both instruments aim at ensuring that notifications of illegal hate speech are assessed against the law and not only against the internal terms of service of the IT companies and that the assessment is made expeditiously. An important difference is that the scope of application of the German law goes beyond the Code of Conduct in so far that it includes also other offences, such as defamation 19

Nevertheless, the analysis noted that the NetzDG threatens regulatory harmonization as outlined in the Juncker Commission's Digital Single Market Strategy, writing that "The Commission considers that national solutions at this respect can lead to unwanted legal fragmentation and have a negative effect on innovation." 20 It was clear to officials working in the Commission that the NetzDG was on shaky legal footing. It quite clearly ran against the country of origin principle established in Article 3 of the E-Commerce Directive (Spindler, 2017), which states that Member States may not "restrict the freedom to provide information society services from another Member State" (Hellner, 2004, p. 9) ${ }^{21}$ and also had issues on free expression grounds with European Human Rights law as set out under the European Convention on Human Rights and other measures.

As a Commission official involved in the debates at the time discussed, "it was obvious to everyone who had been following the debates in Germany that NetzDG had major issues under European law.' 22 However, the situation was just ambiguous enough that what the Commission would do was a political, and not purely legal question. As the official explained, notifying a new law triggered an informal political and legal assessment, and not a fundamental rights compliance assessment, which would only be triggered in the case of the notified proposal transposing European Law (for example, in the case of an amendment to the Telemediengesetz, the German transposition of the ECommerce Directive). The stakes were high: as one staffer for a Member of the

\footnotetext{
${ }^{19}$ Gorwa FOIA to DG JUST, 2020 Document received June 16, 2020, and dated June 8, 2017, page 5 .

${ }^{20}$ Ibid.

${ }^{21}$ Article 3 of the ECD is legally complex and has been interpreted slightly differently by various member states in their implementations of the ECD. See Hellner (2004) for a detailed discussion.

${ }^{22}$ Interview held in 2019 with anonymous Commission (DG CNECT) staffer.
} 
European Parliament working on digital policy issues at the time put it, "the consensus was that early law made by a major member state could serve as a blueprint for eventual European wide legislation." 23

In effect, the Commission had three formal options. It could issue a comment, a non-binding public response which would advise the German Ministry on changes that the Commission recommended; it could issue a so-called 'detailed opinion' similar to a comment, except one which mandated a reply from the German government and had the additional effect of extending the standstill period by at least a month; or it could try and negotiate these issues off the record via direct negotiations. Because of the timing of the German notification, a detailed opinion would extend the standstill into the Bundestag's summer vacation, and thus past the last session of parliament, effectively killing the proposal.

\subsection{Final Negotiations}

The NetzDG debate continued to heat up in Berlin and Brussels. On the 11th of April, a coalition of non-governmental actors had published an open letter in German against the NetzDG. This "unusually broad" group (Reuter, 2017e) of civil society organizations and industry associations, many of whom frequently clashed on digital policy issues, were joined by "journalists, lawyers, academics, and even one former minister of justice" in an alliance calling itself the "Alliance for Freedom of Opinion" (He, 2020, p. 31). This group included the partyaffiliated digital policy think tanks for the SPD and CDU, as well as many other high-profile individuals, and called for a consultation around the NetzDG as they sought to build public support against the law.

In Brussels, a high-level meeting about the NetzDG happened on May 23 with members of the cabinet for Commissioners Ansip, Jourova, Juncker, and Timmermans. As an internal emailed summary of that meeting discusses, Vice President Ansip (who was also Commissioner for the Digital Single Market, and thus in charge of DG CNECT) "wished to send a political letter to DE on the main concerns [CNECT] have on the draft law," but Juncker, Timmermans, and Jourova did not want to co-sign it ${ }^{24}$ While Ansip argued on the side of maintaining harmonization and getting Germany to stand down, the others were hesitant due to a number of political factors. The main one articulated in interviews with officials present at these discussions was that Germany was entering an election year, and there was a perception that if the Commission stepped in and deemed the NetzDG in violation of EU law it might be seen as a domestic political defeat for Maas and the SPD, potentially affecting the electoral outcome in some way 25 A second issue was the historical sensitivity of hate speech in Germany (Tworek, 2021), and the significant pressure coming from

\footnotetext{
${ }^{23}$ Interview in 2020 with Mathias Schindler, Office of Member of European Parliament Julia Reda (The Greens/European Free Alliance, (2014-2019))

${ }^{24}$ Gorwa FOIA to DG CNECT, 2020. Document received July 10, 2020, and dated May $24,2017$.

${ }^{25}$ Interview held in 2020 with anonymous DG CNECT and DG JUST staffers.
} 
German policymakers, including prominent German staffers in the European Commission, for this issue should be left aside as a domestic political matter. Finally, while the DGs may have wished to regulate the issue of harmful content in a different manner than Germany, the Commission had no viable alternative currently in the works that it could propose to Germany, other than the Commission's Hate Speech code of conduct, which followed a similar collaborative approach as the Task Force and was already seen as ineffectual by the German negotiating team 26

Industry and civil society tried to exert pressure on the Commission to intervene. Many of the groups building public relations campaigns against the NetzDG in Germany also wrote direct comments on the law to the European Commission through the TRIS portal, further making their opposition to the law felt through both formal and informal channels. In a meeting with DG GROW's cabinet on June 12, Facebook's lead Brussels lobbyist argued that the NetzDG violated the E-Commerce Directive and sought for the Commission to engage in "a dialogue with the German authorities to change the law." ${ }^{27}$ A scene-setter with talking points prepared for Commission official leading the meeting outlines DG GROW's position on the burning question that Facebook was guaranteed to ask: "Does the EC intend to object to the notified German draft" ? (The talking point demurs, noting that "The commission is still assessing the compatibility of the Draft Act notified by Germany with EU Law. The deadline for reaction expires... on 28 June 2017" ).

Much of European politics operates outside of formal procedures in the realm of informal governance (Kleine, 2013). Technically, if the Commission had a legal issue with the law it should offer a detailed opinion or issue public comments; instead, the Commission raised concerns through informal letters and other backchannels that would minimize domestic fallback for a German government set on passing the law before the election ${ }^{28}$ On June 27, 2016, the grand coalition introduced an amended version of the bill, "revised in consultation with the Commission in order to achieve the greatest degree of compatibility with EU law" into the Bundestag's Legal Affairs committee ${ }^{29}$ Firstly, the scope of the law was changed slightly, by narrowing the definition of social networks so that it excluded peer-to-peer messaging services, music services, blogs, and other platforms. Combined with a threshold of 2 million registered users in Germany, the law was crafted so that it would at its onset only apply to Twitter, Facebook, and YouTube. Secondly, the list of sections of the German Criminal Code that companies would need to check flagged content against was trimmed down, removing a few statutes that had been critiqued by civil society as be-

\footnotetext{
${ }^{26}$ Interview held in 2020 with Prabhat Agarwal, head of DG CNECT unit on E-commerce \& Online Platforms.

${ }^{27}$ Gorwa FOIA to DG GROW, 2020. Document received June 9, 2020; document dated July 6, 2017.

${ }^{28}$ These communications have still not been released, with multiple efforts to obtain it via freedom of information requests available on AsktheEU that have been denied by the Commission.

${ }^{2 \mathrm{~g}}$ See Gorwa FOIA to DG GROW, 2020. Germany's Response to Sweden, received June 9, 2020; document dated July 28, 2017.
} 
ing redundant and not pertaining to hate speech (e.g. the statues referring to defamation of the Federal President or the 'denigration of constitutional organs' like the courts). Additionally, the new version removed two of the major provisions that had been added post-Task Force: the provision that firms should have a 'stay down' filter by which they would algorithmically search for, and remove, duplicate content from their platforms when removing an image or video for violating one of the criminal statutes specified in NetzDG, and the provision that the companies would need to archive content deleted for federal prosecutors, which critics argued was especially problematic from a data protection point of view (Reuter, 2017c). Finally, the new version added a provision which allowed for the role of 'regulated self-regulation' to be involved in the reporting or assessment of cases of illegal content reported by users, a prospective safeguard that was being advocated for by the CDU faction.

The Legal Affairs committee approved this new version, and set a date for the second reading of the bill in the Bundestag three days later, June 30, the last day the Bundestag was in session before the 2017 election. On June 30, the NetzDG was debated on the floor of parliament for 45 minutes. The parties continued to express the positions that they had vocalized throughout the legislative process. Parliamentarians from the Greens and the Left noted that the bill remained problematic, despite the changes, as its core element, the 24-hour removal period backed by fines, was unchanged. Renate Künast, a member of the Greens who sat on the legal affairs committee and had chaired an expert hearing on the NetzDG, worried that through the NetzDG the Bundestag was setting a "fundamental course for the digital age... [and] Even undemocratic countries are looking at us." She suggested that the NetzDG was just providing a surface level solution to a much deeper problem: as the Bundestag's press office summarized, "instead of a rapid legislative process, [Künast] would have liked to see a broader debate on what was going on in society that would lead to such [problematic] forms of expression on the Internet" (Deutscher Bundestag, 2017a, author translations). Following the second reading, as no amendments were made, the Bundestag proceeded immediately to the third reading and final vote. The law passed through the votes of the majority coalition (CDU/CSU and SPD), with the AfD and Linke voting against, and the Greens abstaining.

A few days after the vote, it was evident that many lawmakers, even within the grand coalition, were not thrilled with the law, but nevertheless maintained that it was the best of bad options, given the lack of time, and the institutional constraints in place. In an interview with the left-wing daily Tageszeitung, the SPD's legal policy spokesperson Johannes Fechner argued that the NetzDG supplied imperfect rules to meet what was a crucially important demand, noting that while the SPD wished to have added more provisions that would have better protected the freedom of expression of users,

But if we had included a new obligation for companies in the law, we would have had to re-notify the law to the EU. We would then have had to wait another three months to find out whether there were concerns on the part of the EU Commission or other EU states. So 
the law could not have been passed in this legislative period. (Rath, 2017 , author translation)

Fechner's comment highlights the lock-in effects that were born as a result of the EU's institutional framework and the time period (only 2 years) in which Germany sought to meaningfully change the regulatory status quo. By having a first-mover advantage, and being the first effort to move meaningfully on the issue of platform content rules before the major increase in domestic demand for new rules happened, the Task Force's approach effectively became the only feasible option for legislation before the election happened. While lawmakers across all parties were initially dissatisfied with the NetzDG's design, the EU's notification procedure (and Germany's informal parliamentary discontinuity principle) in effect meant that no other alternative was on the table, and that major changes to the law's structure could not be made, as any substantively new legal framework would have to have been re-notified to the Commission. Given these constraints, multiple interviewees across the governing coalition expressed the argument that the NetzDG was clearly imperfect, and did not fully succeed at remedying the issues it had been drawn up to achieve. Nevertheless, as one staffer put it, it was better than having done nothing, and may have been "the best of bad options" available at the time ${ }^{30}$ a first step, a reassertion of the primacy of German law over foreign corporate power, a way to coerce firms to the table and to make some incremental changes, and perhaps a less-than-ideal outcome, but one which was born within a specific political and institutional context.

\section{Conclusion}

There is a tendency in intermediary liability and content moderation scholarship, found even in the most critical and holistic approaches, to focus on the implications and features of a specific governance system without fully exploring the political factors that led to them, the strategies deployed by the different actors in the contestation that shaped the law, and the ways that certain policy avenues may have become closed due to early decisions and path dependencies. This article suggests that an approach grounded in regulatory politics can provide some analytical tools to widen that current conversation.

Because the NetzDG was the first national law to explicitly move beyond general liability structures and assess exactly how companies conduct content moderation, it is a vital case for understanding how and why platform content regulation occurs, and why it may evolve away from a softer voluntary and towards a harder legislative approach. The account presented here demonstrates how an inductive and qualitative empirical strategy can lead to unexpected insights, such as an analysis of a fairly obscure institutional mechanism (the TRIS notification process) that is wholly unexplored in scholarship on the topic

${ }^{30}$ Interview held in 2020 with an anonymous governing coalition digital policy staffer. 
and yet was incessantly mentioned in stakeholder interviews as a key factor in the NetzDG negotiations.

Regulatory politics, and the institutions that underpin it, are complex and rich sources of political interaction. The account presented here, which focused on process, is necessarily limited, as it emphasized live primary documents and interview material dealing with the immediate nature of political contestation rather than providing a longer-term, historical analysis of structuring institutional factors, such as the historical, cultural, social, and political terrain upon which German policymaking occurs (especially pertaining to freedom of expression issues, see Tworek, 2021). Nevertheless, it sought to provide an idea of how a regulatory politics approach and method can contribute a more comprehensive understanding of the political realities of platform regulation, and provide an entry point for structured comparative work — for instance, re-assessing these findings in the context of recent German efforts to pass NetzDG amendments (Heldt, 2020), and copycat legislation passed by the Austrian government once again facing the institutional resistance of the European Commission (Fischer et al., 2020). Future research is needed to further understand the various political, institutional, and normative factors drivers underpinning the recent developments in platform content governance in both the European context and beyond.

\section{Acknowledgements}

Firstly, many thanks to the various funders supporting my doctoral research, especially the Social Science and Humanities Research Council of Canada, and the Canadian Centennial Scholarship Fund. This research was conducted largely from Berlin, where I was fortunate enough to be hosted by two fantastic research institutions, the Weizenbaum Institute for the Networked Society and the Alexander von Humboldt Institute for Internet and Society. Special thanks to Thorsten Theil at the Weizenbaum Institute and Nicolas Friederici at the HIIG for their invitation and extraordinary hospitality. Early versions of this article were presented at the European Consortium for Political Research and GIGANET annual conferences, as well as the WZB Berlin Social Science Centre POLDI-POGO colloquium; thanks to all participants for their comments and feedback. Many thanks in particular to those that took the time to provide comments at various stages of this project, especially Matthias Kettemann, Jeanette Hofmann, Thorsten Theil, and Julian Juarsch. A huge additional thanks to my interview participants and informants, most of whom somehow made the time to participate in an interview during a pandemic. All errors and omissions remain my own. Finally, a special heartfelt thanks to the colleagues that helped connect me with interview participants, especially Torben Klausa, Robert Madellin, Vera Weidmensch, Stefan Theil, and Wolfgang Schulz. An extra final thanks to Arne Semstrott and Alexander Fanta for their help with FOIA strategies. 


\section{References}

Arun, C. (2018). Rebalancing Regulation of Speech: Hyper-Local Content on Global Web-Based Platforms (SSRN Scholarly Paper ID 3108238). Social Science Research Network.

Baistrocchi, P. A. (2002). Liability of intermediary service providers in the EU Directive on Electronic Commerce. Santa Clara Computer \& High Technology Law Journal, 19, 111.

Bannerman, S., \& Haggart, B. (2015). Historical institutionalism in communication studies. Communication Theory, 25(1), 1-22.

Beckedahl, M. (2016). Brief von Maas an Facebook. Frag Den Staat.

BMFSFJ. (2016). Hassbotschaften in Sozialen Netzwerken wirksam bekämpfen. Bundesfamilienministerium.

Claussen, V. (2018). Fighting hate speech and fake news. The Network Enforcement Act (NetzDG) in Germany in the context of European legislation. Rivista Di Diritto Dei Media, 3, 1-27.

Dernbach, A. (2015). Germany suspends Dublin agreement for Syrian refugees. Euractiv,

Deutscher Bundestag. (2017a). Bundestag beschließt Gesetz gegen strafbare Inhalte im Internet. Deutscher Bundestag.

Deutscher Bundestag. (2017b). Kontroverse um Gesetzentwurf gegen Hasskriminalität im Internet. Deutscher Bundestag.

Digitale Gesellschaft. (2021). NetzDG und mehr. Digitale Gesellschaft

Dostal, J. M. (2015). The Pegida Movement and German Political Culture: Is Right-Wing Populism Here to Stay? The Political Quarterly, 86(4), 523-531.

Farrell, H., \& Newman, A. L. (2010). Making global markets: Historical institutionalism in international political economy. Review of International Political Economy, 17(4), 609-638.

Fischer, G., Kettemann, M. C., \& Rachinger, F. (2020). Cosi fan tutte: Some Comments on Austria's Draft Communications Platforms Act (SSRN Scholarly Paper ID 3731593). Social Science Research Network.

Frag den Staat. (2017). Task Force: Umgang mit rechtswidrigen Hassbotschaften im Internet. Frag den Staat,

Frosio, G. F. (2017). Reforming intermediary liability in the platform economy: A European digital single market strategy. Northwestern University Law Review, 112, 19-46.

Frosio, G. F. (2018). Why keep a dog and bark yourself? From intermediary liability to responsibility. International Journal of Law and Information Technology, 26(1), 1-33.

Gathmann, F. (2015). Heidenau: Sigmar Gabriel besucht Flüchtlingsunterkunft. Der Spiegel.

Gathmann, F., \& Knaup, H. (2017). Heiko Maas zu Machtanspruch von Martin Schulz: "Alles andere wäre armselig". Der Spiegel.

Gillespie, T. (2018). Custodians of the Internet: Platforms, content moderation, and the hidden decisions that shape social media. New Haven, CT: Yale University Press. 
Gillespie, T., Aufderheide, P., Carmi, E., Gerrard, Y., Gorwa, R., MatamorosFernández, A., Roberts, S. T., Sinnreich, A., \& West, S. M. (2020). Expanding the debate about content moderation: Scholarly research agendas for the coming policy debates. Internet Policy Review, 9(4), 1-29.

Glaser, S., Günter, T., Schindler, F., \& Steinle, M. (2008). Protection of Minors on the Internet. Jugendschutz Annual Report.

Gollatz, K., \& Jenner, L. (2018). Hate speech and fake news - how two concepts got intertwined and politicised. HIIG Digital Society Blog.

Gorwa, R. (2019a). The platform governance triangle: Conceptualising the informal regulation of online content. Internet Policy Review, 8(2), 1-18.

Gorwa, R. (2019b). What is platform governance? Information, Communication \& Society, 22(6), 854-871.

Haggart, B. (2014). Copyfight: The global politics of digital copyright reform. Toronto, CA: University of Toronto Press.

He, D. (2020). Governing Hate Content Online: How the Rechtsstaat Shaped the Policy Discourse on the NetzDG in Germany. International Journal of Communication, 14, 23.

Heldt, A. (2019a). Reading between the lines and the numbers: An analysis of the first NetzDG reports. Internet Policy Review, 8,(2).

Heldt, Amélie. (2019b). Let's Meet Halfway: Sharing New Responsibilities in a Digital Age. Journal of Information Policy, 9, 336-369.

Heldt, Amelie. (2020). Germany is amending its online speech act NetzDG... But not only that. Internet Policy Review.

Hellner, M. (2004). Country of Origin Principle in the E-commerce DirectiveA Conflict with Conflict of Laws. European Review of Private Law, 12, 193.

Hinger, S. (2016). Asylum in Germany: The Making of the "Crisis" and the Role of Civil Society. Human Geography, 9(2), 78-88.

Jugendschutz. (2016). Ergebnisse des Monitorings von Beschwerdemechanismen jugendaffiner Dienste. Jugendschutz Online.

Karpf, D. (2017). Digital Politics After Trump. Annals of the International Communication Association, 41(2), 198-207.

Kaye, D. (2019). Speech Police: The Global Struggle to Govern the Internet. New York, NY: Columbia Global Reports.

Keller, D. (2018). The Right Tools: Europe's Intermediary Liability Laws and the EU 2016 General Data Protection Regulation. Berkeley Technology Law Journal, 33, 287-364.

Kettemann, M. C., \& Schulz, W. (2020). Setting Rules for 2.7 Billion: A (First) Look into Facebook's Norm-Making System. Hans-Bredow-Institut.

Kirschbaum, E. (2015). German justice minister takes aim at Facebook over racist posts. Reuters.

Kleine, M. (2013). Informal governance in the European Union: How governments make international organizations work. Ithaca, NY: Cornell University Press.

Klonick, K. (2017). The New Governors: The People, Rules, and Processes Governing Online Speech. Harvard Law Review, 131(6), 1598-1670.

Krauss, M. (2015). Null Toleranz bei Hassparolen. Jüdische Allgemeine. 
Kuczerawy, A. (2018). Intermediary Liability and Freedom of Expression in the EU: From concepts to safeguards. Cambridge, UK: Intersentia.

Leech, B. L. (2002). Interview Methods in Political Science. Political Science \& Politics, 35(4), 663-664.

Liesching, M. (2017). NetzDG-Entwurf basiert auf Bewertungen von Rechtslaien. beck-community.

Livingstone, S., Olafsson, K., O’Neill, B., \& Donoso, V. (2012). Towards a better internet for children: Findings and recommendations from EU Kids Online to inform the CEO coalition. London, UK: EU Kids Online.

Marsden, C. T. (2011). Internet co-regulation: European law, regulatory governance and legitimacy in cyberspace. Cambridge, UK: Cambridge University Press.

Mattli, W., \& Woods, N. (Eds.). (2009). The Politics of Global Regulation. Princeton, NJ: Princeton University Press.

Medzini, R. (2021). Enhanced self-regulation: The case of Facebook's content governance. New Media \& Society, 1461444821989352.

Rath, C. (2017). SPD-Politiker über Facebook-Gesetz: 'Legale Posts wiederherstellen.' Die Tageszeitung.

Reinbold, F. (2015). Hetze auf Facebook: Warum der Hass nicht gelöscht wird. Der Spiegel.

Reporters Without Borders Germany. (2017, November 4). Breite Allianz für Meinungsfreiheit. RSF.

Reuter, M. (2017a). Bundestagsdebatte: Maas findet sein Hate-SpeechGesetz gut, alle anderen wollen Änderungen. netzpolitik.org.

Reuter, M. (2017b). Hate-Speech-Gesetz: Geteilte Reaktionen auf den Entwurf des Justizministers. netzpolitik.org.

Reuter, M. (2017c). Hate-Speech-Gesetz: Neuer Entwurf gefährdet weiterhin die Meinungsfreiheit. netzpolitik.org.

Reuter, M. (2017d). Hate Speech: Union und SPD wollen KlarnamenInternet durch die Hintertüre. netzpolitik.org.

Reuter, M. (2017e). Vorsicht Beruhigungspille: Netzwerkdurchsetzungsgesetz geht unverändert in den Bundestag. netzpolitik.org.

Reuters. (2016). German Minister Tells Facebook to Get Serious About Hate Speech. Fortune

Schulz, W. (2018). Regulating Intermediaries to Protect Privacy Online: The Case of the German NetzDG (SSRN Scholarly Paper No. ID 3216572). Rochester, NY: Social Science Research Network.

Schulz, W. (2019). Roles and Responsibilities of Information Intermediaries. Hoover Aegis Paper, 1904. Palo Alto, CA: Hoover Institution, Stanford University.

Spindler, G. (2017). Internet Intermediary Liability Reloaded: The New German Act on Responsibility of Social Networks and its (In-) Compatibility with European Law. Journal of Intellectual Property, Information Technology and E-Commerce Law, 8(2).

Stupp, C. (2018, January 19). Jourova: 'Never say never' to EU hate speech law. Euractiv. 
Suzor, N. (2019). Lawless: The secret rules that govern our digital lives. Cambridge, UK: Cambridge University Press.

Theil, S. (2019). The Online Harms White Paper: Comparing the UK and German approaches to regulation. Journal of Media Law, 1-11.

Tworek, H. (2021). Fighting Hate with Speech Law: Media and German Visions of Democracy. The Journal of Holocaust Research, 35(2), 106-122.

Tworek, H., \& Leerssen, P. (2019). An Analysis of Germany's NetzDG Law. Ditchley Park, UK: Transatlantic High Level Working Group on Content Moderation Online and Freedom of Expression.

Vasagar, J. (2014). Transcript of interview with Heiko Maas, German justice minister. Financial Times.

Westerwinter, O. (2021). Transnational public-private governance initiatives in world politics: Introducing a new dataset. The Review of International Organizations, 16, 137-174.

Wischmeyer, T. (2018). "What is Illegal Offline is Also Illegal Online" The German Network Enforcement Act 2017 (SSRN Scholarly Paper No. ID 3256498). Rochester, NY: Social Science Research Network. 


\begin{tabular}{|c|c|c|c|}
\hline Name & Organization & Title & Date (D.M.Y) \\
\hline Prabhat Agarwal & European Commission (DG Connect) & Head of Unit for Online Platforms & 15.05 .2020 \\
\hline Owen Bennett & Mozilla Corporation & Internet Policy Manager & 29.04 .2020 \\
\hline Mario Brandenburg & The Free Democratic Party of Germany & Member of the Bundestag (2017-) & 18.06 .2020 \\
\hline Tony Close & Facebook & Director of Content Regulation (Global) & 20.04 .2021 \\
\hline Barbara Docklova & Article 19 & Senior Campaigner & 6.05 .2020 \\
\hline Alexander Fanta & Netzpolitik & Brussels Correspondent & 8.04 .2020 \\
\hline $\begin{array}{l}\text { Gabrielle Guillemin } \\
\text { Julian King }\end{array}$ & $\begin{array}{l}\text { Article } 19 \\
\text { European Commission }\end{array}$ & $\begin{array}{l}\text { Digital Rights Lead } \\
\text { Commissioner for the Security Union (2016-2020) }\end{array}$ & $\begin{array}{l}2.07 .2020 \\
20.052000\end{array}$ \\
\hline $\begin{array}{l}\text { Julian King } \\
\text { Lubos Kuklis }\end{array}$ & $\begin{array}{l}\text { Europeann Commission } \\
\text { European Regulators Group for Audiovisual Media Services (ERGA) }\end{array}$ & $\begin{array}{l}\text { Commissioner for the Security Union (2016-2020) } \\
\text { Clanir }\end{array}$ & $\begin{array}{l}20.05 .2020 \\
16.062000\end{array}$ \\
\hline $\begin{array}{l}\text { Lubos huchis } \\
\text { Lutz Mache }\end{array}$ & $\begin{array}{l}\text { European Regunators Group for Audrovisual Media Services (ERGA) } \\
\text { Google Germany }\end{array}$ & $\begin{array}{l}\text { Charr } \\
\text { Public Policy and Government Relations Manager }\end{array}$ & $\begin{array}{l}16.06 .2020 \\
30.042020\end{array}$ \\
\hline Robert Madellin & European Commission (DG Connect) & Director General (2010-2015) & 12.05 .2020 \\
\hline Joe McNamee & European Digital Rights & Executive Director (2009-2019) & 15.05 .2020 \\
\hline $\begin{array}{l}\text { Mackenzie Nelson } \\
\text { Paul Nenitz }\end{array}$ & Algorithm Watch & 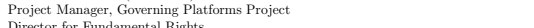 & $\begin{array}{l}28.04 .2020 \\
50.2020\end{array}$ \\
\hline $\begin{array}{l}\text { Paul Nemitz } \\
\text { Javier Pallero }\end{array}$ & $\begin{array}{l}\text { European Commission (DG Justice) } \\
\text { Acress Now }\end{array}$ & $\begin{array}{l}\text { Director for Fundamental Rights } \\
\text { Head of Policr }\end{array}$ & 5.06 .2020 \\
\hline Jörn Pohl & The Green Party of Germany & $\begin{array}{l}\text { Chief of Staff, MdB Konstantin von Notz } \\
\text {. }\end{array}$ & 8.05 .2020 \\
\hline Simone Rafael & Amadeu Antonio Stiftung & Executive Director & 5.06 .2020 \\
\hline $\begin{array}{l}\text { Julia Reda } \\
\text { Alexander Ritzmamn }\end{array}$ & European Parliament & Member of the European Parliament (2014-2018), The Greens-European Free Alliance & 27.04 .2020 \\
\hline $\begin{array}{l}\text { Alexander Ritzmann } \\
\text { Mathias Schindler }\end{array}$ & $\begin{array}{l}\text { Counter Extremismm Project } \\
\text { European Parliament }\end{array}$ & 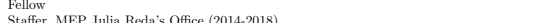 & $\begin{array}{l}10.06 .2020 \\
20.042000\end{array}$ \\
\hline $\begin{array}{l}\text { Mathias Shchindler } \\
\text { Wolfgang Schulz }\end{array}$ & $\begin{array}{l}\text { Europeana Parliament } \\
\text { Alexander von Humboldt Institute for Internet and Society }\end{array}$ & $\begin{array}{l}\text { Staffer, MEP Julia Reda's Office (2014-2018) } \\
\text { Director }\end{array}$ & $\begin{array}{l}20.04 .2020 \\
9.04 .2020\end{array}$ \\
\hline Matthias Spielkamp & Algorithm Watch & Director & 30.06 .2020 \\
\hline Mathias Vermeulen & European Parliament & Staffer, MEP Marietje Schaake (Alliance of Liberals and Democrats for Europe) & 2.07 .2020 \\
\hline & Social Democratic Party of Germany & Member of the Bundestag (2013 - & \\
\hline
\end{tabular}

Table 1: Non-anonymized interviews

\begin{tabular}{|c|c|c|c|}
\hline Request Title & Target & Date & Link \\
\hline & m der Justiz und für Verb & 09.06 .2020 & https://fragdenstaat.de/anfrage/netzdg-notifizier \\
\hline & Bundes & 09.06 .2020 & 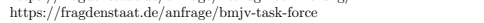 \\
\hline Breife an Internetkonzerne & Bundesministerium der Justiz und für Verbraucherschutz & 15.07 .2020 & 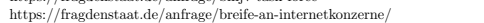 \\
\hline & DG GROW, DG CNECT, DG JUST & 20.04 .2020 & 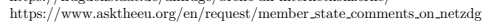 \\
\hline Notification on NetzDG Amer & DG GROW & 20.04 .2020 & 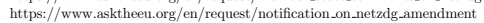 \\
\hline
\end{tabular}

Table 2: FOI requests, with links to archived documents 